to move resources in the direction of primary care. Yet as constraints on funding begin to bite a new dynamic is becoming apparent. This involves combined action by hospital providers, who have fulfilled their contracts with a quarter of the year remaining, and general practitioners, who as a consequence are unable to obtain hospital treatment for their patients, to put pressure on health authorities to increase the resources available to acute services. Operating under budgets constrained by the government's public expenditure policies, health authorities can do little other than wait until the new financial year before they provide extra funds for hospitals. In the meantime fundholding practices can use the spare capacity that exists. As this happens equity is sacrificed as purchasing power rather than clinically diagnosed need determines which patients should be treated. It can be only a matter of time before stories of patients being denied care because of lack of resources are in the headlines. To this extent the wheel has turned full circle and the NHS is back where it was when Mrs Thatcher was so irritated by stories of bad news about health services that she announced her review of the NHS.

What this illustrates is that, notwithstanding the progress made in the past two years, the reforms in themselves have done little to compensate for the long term underfunding of the NHS. Not only that, they have also accentuated the impact of constraints on funding by encouraging purchasers to favour those hospitals that are efficient and responsive to patients. Those who gain from this process-whether in primary or secondary care-are matched by others who lose in the zero sum game that resource allocation in the NHS has become. On the principle that losers always shout louder than winners, a winter of discontent is in prospect. What price another NHS review?

CHRIS HAM

Professor,

Health Services Management Centre,

University of Birmingham,

Birmingham B15 2RT

\title{
How useful is activated charcoal?
}

\section{Studies have left many unanswered questions}

Charcoal will adsorb most poisons, at least to some extentthough laboratory studies suggest that lithium, iron, cyanide, and strong acids and alkalis are the exceptions. Charcoal is prepared from vegetable matter and petroleum, and "activation" creates a highly developed internal pore structure, thereby increasing the surface area from $2-4 \mathrm{~m}^{2} / \mathrm{g}$ to more than $1000 \mathrm{~m}^{2} / \mathrm{g}$. The therapeutic potential of charcoal adsorption seems high, but three questions need to be answered. Should charcoal be given indiscriminately to every patient who has swallowed a poison? Could it replace the trauma, indignity, and inefficiency of induced vomiting and gastric lavage? And which poisons can be eliminated more rapidly by repeated doses of charcoal?

Though a few reports suggest no benefit, ${ }^{1-4}$ others have shown that, when given 30 to 60 minutes later, a single dose of charcoal reduces the absorption of aminophylline, ${ }^{1}$ ampicillin, ${ }^{5}$ aspirin, ${ }^{67}$ carbamazepin, ${ }^{8}$ digoxin, ${ }^{6}$ doxepin, ${ }^{9}$ mefenamic acid, ${ }^{10}$ paracetamol, ${ }^{11}$ phenobarbitone, ${ }^{8}$ phenytoin, ${ }^{6}$ tetracycline, ${ }^{1}$ theophylline, ${ }^{12}$ and tolfenamic acid. ${ }^{4}$ All these studies, however, were done on fasting volunteers given non-toxic doses and a comparatively large dose of charcoal (usually $50 \mathrm{~g}$ ). The results are of doubtful relevance to clinical settings in which an uncertain - but usually larger-amount of drug has been taken after food and often in association with alcohol and other drugs. The lack of satisfactory studies on the use of activated charcoal in reducing drug absorption in poisoned patients is largely because the task is so difficult.

Comparative studies in volunteers have shown that activated charcoal is better than either syrup of ipecacuanha ${ }^{71314}$ or gastric lavage ${ }^{5}$ in reducing drug absorption. This conclusion has been supported by observations in patients poisoned with paracetamol. ${ }^{15}$ Nevertheless, it has not yet been shown that in these circumstances charcoal reduces the need for an antidote.

Turning to the third question, repeat doses of activated charcoal are thought to act in several ways. Firstly, the charcoal adsorbs unabsorbed poison still present in the gut. This is particularly relevant in the cases of slow release preparations such as theophylline and of drugs that are absorbed slowly because they decrease gastric motility (for example, tricyclic antidepressants). Next, charcoal adsorbs drugs that are secreted in bile, thereby preventing their enterohepatic recirculation. Thirdly, charcoal binds any drug that diffuses from the circulation into the gut lumen, thus interrupting the enteroenteric circulation. After absorption a drug will re-enter the gut by passive diffusion provided that the concentration there is lower than that in the blood. The amount diffusing depends on the concentration gradient, the intestinal surface area, the permeability of the mucosa, and blood flow. Immediate adsorption of the drug by charcoal in the lumen ensures that the concentration gradient is kept as high as possible and that diffusion continues. A few unusual drugs such as digoxin may be secreted actively by the intestinal mucosa, but this process is unlikely to contribute more than passive diffusion does to the effect of activated charcoal on drug clearance. Again much of the published evidence comes from studies in volunteers, which have shown that repeated doses of activated charcoal increased the elimination of amitriptyline, ${ }^{16}$ carbamazepine, ${ }^{8}$ dapsone, ${ }^{17}$ doxepin, ${ }^{9}$ digoxin, ${ }^{18}$ digitoxin, ${ }^{19}$ phenobarbitone, ${ }^{8}$ phenytoin, ${ }^{20}$ phenylbutazone, ${ }^{8}$ and theophylline ${ }^{21}$ but not of imipramine ${ }^{22}$ or salicylate. ${ }^{23}$ Studies in poisoned patients have confirmed these observations in the case of carbamazepine, ${ }^{24}$ dapsone, ${ }^{25}$ digoxin, ${ }^{26}$ phenobarbitone, ${ }^{27}$ phenytoin, ${ }^{28}$ and theophylline. ${ }^{29}$ There is also evidence that, contrary to findings in volunteers, activated charcoal will increase the elimination of salicylates, ${ }^{30}$ possibly because drug metabolising enzyme systems are fully saturated at the higher plasma concentrations attained in cases of acute poisoning. A beneficial effect has also been claimed in dothiepin poisoning. ${ }^{31}$

What conclusions can be drawn? Most patients coming to hospital after an overdose are not at serious risk. The challenge is to identify at an early stage those who are most at risk of developing serious complications so that appropriate treatment may be given. More information is required before gastric lavage can be abandoned completely in favour of giving activated charcoal, but a reasonable alternative to lavage would be to give $50-100 \mathrm{~g}$ of activated charcoal to adults who have taken a substantial overdose of a toxic substance no 
more than two hours previously. The management of young children is more difficult-most episodes are poison scares rather than true poisonings. Rather than give young children charcoal immediately on presentation, we suggest confining it to the few who develop symptoms - in a dose sufficient to increase elimination of the drug.

Repeated doses of oral activated charcoal have not yet been shown to reduce morbidity and mortality. Further studies are required to establish its place and the dose to be given. Until these data are available, severely poisoned adults should be given $150-200 \mathrm{~g}$ through a nasogastric tube over 4-8 hours with the aims of achieving a maximum reduction in elimination half life and an improvement in the clinical state. The total dose given is probably more important than the frequency of dosing.

J A VALE

Director

National Poisons Information Service (Birmingham Centre),

West Midlands Poisons Unit,

Dudley Road Hospital,

Birmingham B18 7QH

A T PROUDFOOT

Director

National Poisons Information Service (Edinburgh Centre),

Scottish Poisons Information Bureau,

Royal Infirmary, Edinburgh EH3 9YW

1 Neuvonen PJ, Vartiainen M, Tokola O. Comparison of activated charcoal and ipecac syrup in prevention of drug absorption. Eur 7 Clin Pharmacol 1983;24:557-62.

2 Danel V, Henry JA, Glucksman E. Activated charcoal, emesis, and gastric lavage in aspirin overdose. BMF 1988;296:1507.

3 Scolding N, Ward MJ, Hutchings A, Routledge PA. Charcoal and isoniazid pharmacokinetics. Human Toxicology 1986;5:285-6.

4 Olkkola KT, Neuvonen PJ. Do gastric contents modify antidotal efficacy of oral activated charcoal? Brf Clin Pharmacol 1984;18:663-9.

5 Tenenbein M, Cohen S, Sitar DS. Efficacy of ipecac-induced emesis, orogastric lavage, and activated charcoal for acute drug overdose. Ann Emerg Med 1987;16:838-41

6 Neuvonen PJ, Elfving SM, Elonen E. Reduction of absorption of digoxin, phenytoin and aspirin by activated charcoal in man. Eur f Clin Pharmacol 1978;13:213-8.

Curtis RA, Barone J, Giacona N. Efficacy of ipecac and activated charcoal/cathartic: prevention of salicylate absorption in a simulated overdose. Arch Interm Med 1984;144:48-52.
Neuvonen PJ, Elonen E. Effect of activated charcoal on absorption and elimination of phenobarbitone, carbamazepine and phenylbutazone in man. Eur f Clin Pharmacol 1980;17: $51-7$

Scheinin M, Virtanen R, Iisalo E. Effect of single and repeated doses of activated charcoal on the pharmacokinetics of doxepin. Int f Clin Pharm Ther Toxicol 1985;23:38-42.

10 El-Bahie N, Allen EM, Williams J, Routledge PA. The effect of activated charcoal and hyoscine butylbromide alone and in combination on the absorption of mefenamic acid. $\mathrm{Br} \mathrm{f}$ Clin Pharmacol 1985;19:836-8.

11 NcNamara RM, Aaron CK, Gemborys M, Davidheiser S. Efficacy of charcoal cathartic versus ipecac in reducing serum acetaminophen in a simulated overdose. Ann Emerg Med 1989;18 934-8.

12 Lim DT, Singh P, Nourtsis S, Cruz RD. Absorption inhibition and enhancement of elimination of sustained-release theophylline tablets by oral activated charcoal. Ann Emerg Med 1986;15: 1303-7.

13 Neuvonen PJ, Olkkola KT. Activated charcoal and syrup of ipecac in prevention of cimetidine and pindolol absorption in man after administration of metoclopramide as an antiemetic agent. Clin Toxicol 1984;22:103-1

14 Cordonnier J, Van den Heede M, Heyndrickx A. Activated charcoal and ipecac syrup in prevention of tilidine absorption in man. Vet Hum Toxicol 1987;29(suppl 2):105-6.

15 Underhill TJ, Greene MK, Dove AF. A comparison of the efficacy of gastric lavage, ipecacuanha and activated charcoal in the emergency management of paracetamol overdose. Arch Emerg Med 1990;7:148-54.

16 Swartz CM, Sherman A. The treatment of tricyclic antidepressant overdose with repeated charcoal. f Clin Psychopharmacol 1984;4:336-40.

17 Neuvonen PJ, Elonen E, Mattila MJ. Oral activated charcoal and dapsone elimination. Clin Pharmacol Ther 1980;27:823-7.

18 Lalonde RL, Deshpande R, Hamilton PP, McLean WM, Greenway DC. Acceleration of digoxin clearance by activated charcoal. Clin Pharmacol Ther 1985;37:367-71.

19 Pond S, Jacobs M, Marks J, Garner J, Goldschlager N, Hansen D. Treatment of digitoxin overdose with oral activated charcoal. Lancet $1981 ;$ ii:1177-8.

20 Mauro LS, Mauro VF, Brown DL, Somaru P. Enhancement of phenytoin elimination by multipledose activated charcoal. Ann Emerg Med 1987;16:1132-5.

21 Ilkhanipour K, Yealy DM, Krenzelok EP. The comparative efficacy of various multiple-dose activated charcoal regimens. Am f Emerg Med 1992;10:298-300.

22 Goldberg MJ, Park GD, Spector R, Fischer LJ, Feldman RD. Lack of effect of oral activated charcoal on imipramine clearance. Clin Pharmacol Ther 1985; 38:350-3.

23 Mayer AL, Sitar DS, Tenenbein M. Multiple-dose charcoal and whole-bowel irrigation do not increase clearance of absorbed salicylate. Arch Intern Med 1992;152:393-6.

24 Boldy DAR, Heath A, Ruddock S, Vale JA, Prescott LF. Repeated oral activated charcoal in the treatment of carbamazepine poisoning. Lancet 1987; ;:1027.

25 Neuvonen PJ, Elonen E, Haapanen EJ. Acute dapsone intoxication: clinical findings and effect of oral charcoal and haemodialysis on dapsone elimination. Acta Med Scand 1983;214:215-20.

26 Boldy DAR, Smart V, Vale JA. Multiple doses of charcoal in digoxin poisoning. Lance 985;i:1076-7.

27 Boldy DAR, Vale JA, Prescott LF. Treatment of phenobarbitone poisoning with repeated ora administration of activated charcoal. Qf Med 1986;61:997-1002.

28 Weidle PJ, Skiest DJ, Forrest A. Multiple-dose activated charcoal as adjunct therapy after chronic phenytoin intoxication. Clin Pharm 1991;10:71-4.

29 Sessler CN, Glauser FL, Cooper KR. Treatment of theophylline toxicity with oral activated harcoal. Chest 1985;87:325-9.

30 Hillman RJ, Prescott LF. Treatment of salicylate poisoning with repeated oral charcoal. $B M \mathcal{J}$ 1985;291:1472.

31 Ilett KF, Hackett LP, Dusci LJ, Paterson JW. Disposition of dothiepin after overdose: effects of repeated-dose activated charcoal. Ther Drug Monit 1991;13:485-9.

\title{
The cervical spine in rheumatoid arthritis
}

\author{
Needs careful assessment
}

Rheumatoid arthritis commonly affects the cervical spine, causing several well defined deformities. ${ }^{1}$ Damage to the cervical spine from rheumatoid arthritis has been noted in $30 \%$ to $46 \%$ of necropsy studies and is second in frequency only to that seen in the metatarsophalangeal joints. ${ }^{23}$ One in four inpatients with rheumatoid arthritis and between $17 \%$ and $86 \%$ of all patients with this disease have radiological evidence of instability of the cervical spine. ${ }^{3-6}$

These high rates reflect the anatomy of the cervical spine and the dynamic forces that act on it. Each of the apophysial and ligamentous articulations of the cervical spine is susceptible to the same inflammatory changes as those in peripheral joints of patients with rheumatoid arthritis. ${ }^{2}$ Furthermore, the cervical spine is constrained between a somewhat rigid thoracic spine and a skull weighing $6 \mathrm{~kg}$; movement of the head, which has been estimated to occur around 600 times each hour, adds to the forces on the articulations.

Any segment of the cervical spine may be affected by the rheumatoid inflammatory process, but destructive changes are most prominent at the occipitoatlantoaxial junction. Atlantoaxial subluxation is the most common deformity and is due to destruction and resultant laxity of the transverse ligament. This allows the atlas to move forward relative to the odontoid process of the axis when the neck is flexed. In radiographs this is seen as a widening of more than $3 \mathrm{~mm}$ in the space between the anterior arch of $\mathrm{C} 1$ and the odontoid. The corresponding reduction in the space posteriorly restricts the canal available for the spinal cord. By contrast, posterior subluxation of the atlas is infrequent and is seen only in the presence of severe erosion and dislocation of the odontoid. ${ }^{8}$

Recent studies using magnetic resonance imaging in patients with atlantoaxial subluxation have shown an inflammatory mass of granulation tissue around the odontoid arising from the synovial lining of the articulations. This periodontoid mass is not visible in patients who have had surgical fusion of the first two cervical vertebrae or in whom deformity has progressed to that of atlantoaxial impaction (see below). ${ }^{910}$ The bulging of this mass may further reduce the space available for the spinal cord and cause neurological deficits in patients with only a moderate degree of atlantoaxial subluxation.

When the disease affects one of the occipitoatlantoaxial articulations (termed lateral mass) it may produce the syndrome of non-reducible rotational tilt of the head, the main clinical features of which are occipital pain, tender points in 